SVU- International Journal of Veterinary Sciences, 4(2): 11-26, 2021.

Print ISSN: 2535-1826

\title{
Clinical and microbiological aspect of surgical affections associated with current epidemics in bovine.
}

\section{Hagag Kh. Abdel Kawy'; Ahmed A. Soliman²; Abdel-Nasser A.A. Abdel-Hady ${ }^{1}$ and Waleed Younis $^{3 *}$}

${ }^{1}$ Department of surgery, anesthesiology and radiology, Faculty of veterinary medicine, South Valley University, Qena 83523, Egypt. ${ }^{2}$ Department of surgery, Anesthesiology and radiology, Faculty of veterinary medicine, Cairo University, Cairo University, Giza 12211. ${ }^{3}$ Department Microbiology, Faculty of veterinary medicine, South Valley University, Qena 83523, Egypt.

\section{Abstract}

Egypt is endemic with Lumpy Skin Disease (LSD) and Foot and Mouth Disease (FMD), both impose a drastic effect on the economy. These viral diseases are often complicated with secondary bacterial infections; however, scarce data is available. In this study, utilizing microbiological and molecular procedures, we identified a number of secondary bacterial infections complicating FMDand LSD-infected cases. Moreover, the antimicrobial resistance profile of the bacterial isolates was explored. The data showed that several bacterial pathogens including Serratia odorifera, Enterococcus faecium, Paenibacillus apiaries and Microbacterium hominis could be recovered from LSD-infected cases. On the other hand, FMD cases were found to be complicated with Pseudomonas mosselii, Bacillus cereus and Trueperella pyogens. However, Bacillus licheniformis was isolated from both disease conditions. The antimicrobial testing revealed that all pathogens are resistant to more than three antibiotics of different families, indicating the multi-drug resistant capabilities of these isolates. This baseline investigation confirms the presence of many secondary bacterial infections linked to LSD and FMD as well as the widespread antimicrobial resistance among the isolated pathogens, however, the contribution of these pathogens to the mortality rate in both conditions needs further studies.

Keywords: lumpy skin disease, foot-and mouth-disease, antimicrobial, 16S rRNA sequencing.

DOI: 10.21608/svu.2021.56458.1095 Received: January, 10, 2021 Accepted: March 22, 2021 Published: April 3, 2021 Corresponding Author: Waleed Younis: E-mail: wkhrdr39@gmail.com. Citation: Abdel Kawy et al., 2021 Clinical and microbiological aspect of surgical affections associated with current epidemics in bovine. SVU-IJVS 2021, 4(2):11-26.

Copyright: () Abdel Kawy et al. This is an open access article distributed under the terms of the creative common attribution license, which permits unrestricted use, distribution and reproduction in any medium provided the original author and source are created.

Competing interest: The authors have declared that no competing interest exists.

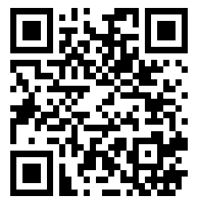




\section{INTRODUCTION}

Epidemic attacks in cattle have been reported to be widely spread in various disease forms all over the world. In Egypt, the most endemic diseases challenging livestock and causing severe financial losses on the national scale are foot-andmouth disease (FMD) and lumpy skin disease (LSD) (Bauer. 1997and Murply et al 1999). Several deleterious effects, such as lowering the productivity and reproductively of affected animals and death were recorded (Fubini and Ducharme 2016) . In addition, the costs and efforts consumed in supportive care and treatment of such complications, especially the surgical one, are alarming (Kossaibati and Esslemont 1997).

LSD was first reported in Egypt in May 3, 1988 (Fayed, 1988 \& Salem, 1989). It occurred in Suez province and the source of infection was imported cattle from Somalia. The causative agent of LSD is a Neethling virus, genus Capri pox virus in the family poxviridae (Murply et al, 1999). There is only one report of the natural occurrence of LSD in species other than cattle, water buffalo (Bubalis), but no further cases are recorded (House, 1998 and Radostits et al, 1994).

An outbreak of LSD infection in different ages and sexes of Egyptian cattle with severe and serious complications was recorded in the summer of 2006, in many Egyptian governorates. Clinical signs, epidemiological characters, electron microscopy and histopathological findings of LSD in this outbreak were reported by Fayez and Ahmed,2011). The skin of different parts of infected animals body such as muzzle, nares, back, limbs, scrotum, perineum, eyelids, ears, nasal and oral mucosa and the tail displayed nodules 1-7 $\mathrm{cm}$ in diameter. The nodules were painful and involved the epidermis, dermis and subcutaneous tissue and further involve the musculature. With the progresses of the disease, the nodules became necrotic with a deep scab (sit fast) forms (El -Kanawaty, 1989; Ismail 1989 and House 1998). Lesions on the udder and teats resulted in mastitis, teat fistula or obstruction (Heidrich and Renk 1967; Ismail 1989 and House 1998). Lameness also may result from secondary bacterial infection. Also, severe edema in the brisket, ventral abdomen and limbs was evident (ElKanawaty, 1989; Kenawy, 1991 and House 1998).

Foot-and-mouth disease virus (FMDV) is a member of the genus Aphthovirus. There are seven major viral serotypes of the virus: O, A, C, SAT 1, SAT 2, SAT 3 and Asia. The most common serotype worldwide is serotype $O$. It is responsible for an Asian pandemic that affected many countries throughout the world began in 1990 (Bauer, 1997). However, serotype $\mathrm{C}$ is uncommon and was not reported since 2004 (Loth et al., 2011). While other serotypes caused serious outbreaks, some FMDV serotypes are more variable than others. However, they may collectively contain more than 60 strains with the potential of development of new strains (Bauer, 1997 and Salt, 1998). While most of the strains affect all susceptible host species, some have a more restricted host range (e.g., serotype O Cathay strain, which only affects pigs). Immune response of animals infected with one FMDV serotype does not protect it from other serotypes infection. Defense against other strains within the same serotype depends on their antigenic determinant similarity (Salt, 1998). Vesicular lesions are the most characteristic feature of FMD (Bauer, 1997).

Since the 1950s, several outbreaks of the FMD affected cattle, buffaloes, sheep, 
goats and camels, with the prevalence of serotype O1 FMD virus (FMDV). Therefore, attention has been drawn to the economic importance of FMD in Egypt (Moussa etal.1974, Daoud et al. 1988 and El-Nakashly et al. 1996). In 2006, the last outbreak due to serotype $(\mathrm{O})$ was reported by Abd El-Rahman et al. (2006). Since1972 serotypes other than $(\mathrm{O})$ have not been reported (Aidaros, 2002). Clinical cases of FMD were recognized on a cattle farm in Ismailia, Northeastern Egypt in 2006. laboratory examination was carried out for clinical samples to determine FMD serotype by using enzyme linked immunosorbent assay (ELISA) test, and reverse transcriptase polymerase chain reaction (RT-PCR). FMDV type (A) was detected and designated as A/Egy/2006 (Knowles et al. 2007). Since 2006, the bivalent (FMD) vaccine, containing both $\mathrm{O} 1$ and A/Egy/2006, was locally produced. After this incident in July 2006, reported FMD outbreaks are caused by either serotype (O1 and A) (GOVS, 2009 and Ghoneim et al., 2010). Mastitis or hoof malformations with accompanying signs of pain are most common complications of FMD infection. In addition, sudden death of young calves due to heart failure without developing vesicles was also reported (Ahmed et al (2012) and Kandeil et al (2013).

Bobkurov (1977) and Frank (1981) stated that knowledge of bacteriology should be used in diagnosis and treatment of surgical infected lesions. They mentioned that the pyogenic bacteria are the most important in acute surgical infections. Micro-organisms are the real causes of epidemic diseases and their complication, either (virus, bacteria, fungi). There are infectious and non-infectious microorganisms, so isolation and identification of micro-organism must be done in proper conditions to ensure the validity of the testing procedure, avoid false positive results due to contamination, and to prevent the spread of infectious microbial agents (EL- Mishad, A (1991)). Therefor the aims of the work are to study the clinical picture of the complications of some current epidemic diseases and management. We attempt to isolate and identify the causative agents of these complications and to perform antibiotic sensitivity tests to choose the best antibiotic to be used to treat bacterial diseases.

\section{MATERIALS AND METHODS}

The present study was carried out on the prevalent clinical and microbiological aspect of surgical affections in bovine in Qena governorate. Most of the cases were registered at the village hospitals and at the owners' houses in the period between April 2018 and April 2020 on a total number of 60 animals (bovine). All cattle were raised on small holding groups and were cross breeds. The study included both sexes and ages from 2 to 4 years, table (1). Clinical findings were systemically identified and evaluated for its nature and severity. Sterile swabs were used to collect samples from different lesions from random 10 cases of LSD (five cases) and Foot FMD (five cases).

\section{Microbiological Study:}

\section{1- Collection of samples:}

Sterile cotton swabs were used to collect samples from different sites (infected nose, mouth, wound, eye, udder and claw) and transferred immediately on ice to our microbiology lab (Department of Microbiology, Faculty of Veterinary Medicine) for microbiological study. 
Table (1): Showing the recorded surgical complications in the studied animals.

\begin{tabular}{|c|c|c|c|c|c|c|c|}
\hline Disease & Sex & Age & $\begin{array}{l}\text { Eye } \\
\text { affection }\end{array}$ & $\begin{array}{l}\text { Mouth } \\
\text { affection }\end{array}$ & $\begin{array}{l}\text { Limb } \\
\text { affection }\end{array}$ & Odema & $\begin{array}{l}\text { Udder } \\
\text { affection }\end{array}$ \\
\hline LSD & M & 1 year & $\begin{array}{l}\text { Nodules in } \\
\text { eye lid }\end{array}$ & $\begin{array}{l}\text { Nodules in gum } \\
\text { and nostril }\end{array}$ & Purulent osselets & $\begin{array}{l}\text { Odema } \\
\text { in brisket }\end{array}$ & No \\
\hline LSD & $\mathbf{F}$ & 2 years & No & No & Purulent osselets & $\begin{array}{l}\text { Odema } \\
\text { in leg }\end{array}$ & $\begin{array}{l}\text { Udder } \\
\text { nodules }\end{array}$ \\
\hline LSD & $\mathbf{F}$ & 3 years & No & No & Purulent osselets & Odema & $\begin{array}{l}\text { nodules and } \\
\text { fistula }\end{array}$ \\
\hline LSD & $\mathbf{M}$ & 2 years & $\begin{array}{l}\text { Corneal } \\
\text { opacity }\end{array}$ & No & $\begin{array}{l}\text { purulent wound } \\
\text { in fore limb }\end{array}$ & Odema & No \\
\hline CSD & $\mathbf{F}$ & 4 years & $\begin{array}{l}\text { Endopthalm } \\
\text { itis }\end{array}$ & No & No & $\begin{array}{l}\text { Odema } \\
\text { in brisket }\end{array}$ & No \\
\hline FMD & M & 1 Years & No & $\begin{array}{l}\text { Vesicles on the } \\
\text { gum and } \\
\text { tongue }\end{array}$ & $\begin{array}{l}\text { coronary band } \\
\text { ulcer }\end{array}$ & No & No \\
\hline FMD & $\mathbf{F}$ & 2 years & No & $\begin{array}{l}\text { swelling of } \\
\text { tongue }\end{array}$ & $\begin{array}{l}\text { coronary band } \\
\text { ulcer }\end{array}$ & No & No \\
\hline FMD & $\mathbf{F}$ & 2 & No & $\begin{array}{l}\text { Vesicular } \\
\text { lesions }\end{array}$ & $\begin{array}{l}\text { coronary band } \\
\text { ulcer }\end{array}$ & No & $\begin{array}{l}\text { Vesicle on } \\
\text { the teat and } \\
\text { abortion }\end{array}$ \\
\hline FMD & $\mathbf{F}$ & 4 Years & NO & $\begin{array}{l}\text { Vesicular } \\
\text { lesions }\end{array}$ & $\begin{array}{l}\text { coronary band } \\
\text { ulcer }\end{array}$ & No & $\begin{array}{l}\text { Blister of } \\
\text { the udder }\end{array}$ \\
\hline FMD & & 3 Years & & $\begin{array}{lr} & \text { Vesicular } \\
\text { lesion } & \text { on } \\
\text { nostril } & \text { and } \\
& \text { mouth }\end{array}$ & $\begin{array}{r}\text { lapping } \\
\text { claw }\end{array}$ & No & Mastitis \\
\hline
\end{tabular}

\section{2- Isolation and identification of microorganisms:}

Sterile cotton swabs were submerged in tryptone soy broth (lab $\mathbf{M}$ ) and incubated at $37^{\circ} \mathrm{C}$ for $18-24$ hour to enhance the growth of microorganism. After incubation, a loopful of each bacterial suspension were streaked on different agar plate (including; blood agar (trypton soya agar $+5 \%$ sheep blood), MacConkey agar (Oxiod) and mannitol salt agar (Himedia) and incubated at $37{ }^{\circ} \mathrm{C}$ for $24-48$ hours with and without $5 \% \mathrm{CO}_{2}$. The macroscopic morphology of the colonies, hemolysis and pigment production were identified according to Quinn et al., 1994 and Sears et al., 1993. Identification of bacteria was carried out by gram staining to detect the microscopical morphology of the bacteria (Forbes et al 2002 and Bebora et al 2007) then subjected to biochemical identification (oxidase test, catalase test and coagulase test). The suspected bacterial isolates were subjected to $16 \mathrm{~S}$ rRNA sequencing to identify genus and species.

\section{3- PCR Identification to bacterial species.}

3.1. DNA extractions from bacterial isolates were done according to QIAamp DNA mini kit manufacture instructions.

3.2. PCR amplification. The amplified 16S rRNA gene was obtained from each isolate and reference strain by PCR with the universal primers F27 (5AGAG TTTGATCMTGGCTCAG-3) and R1492 (5-TACGGYTACCTTGTTAC GACTT-3) (Lagacé et al., 2004), which are targeted to universally conserved regions and permit the amplification of an 
approximately 1485 bp fragments. PCR amplification was carried out in Thermal cycler (Biometra). Reaction tubes contained $25 \mu \mathrm{L}(6 \mu \mathrm{L}$ template DNA, 12.5 $\mu \mathrm{L}$ of Emerald Amp GT PCR master mix (Takara), $1 \mu \mathrm{L}$ of each forward and reverse primer $(20 \mathrm{pmol})$ and $4.5 \mu \mathrm{L}$ of PCR grade water). Initial DNA denaturation and enzyme activation steps were performed at $94{ }^{\circ} \mathrm{C}$ for $15 \mathrm{~min}$, followed by 35 cycles of denaturation at $94{ }^{\circ} \mathrm{C}$ for $30 \mathrm{~s}$, annealing at $56{ }^{\circ} \mathrm{C}$ for $1 \mathrm{~min}$ and extension at $72{ }^{\circ} \mathrm{C}$ for $1 \mathrm{~min}$, and a final extension at $72^{\circ} \mathrm{C}$ for 10 min. The presence and yield of specific PCR product (16S rRNA gene) was monitored on 1\% agarose (BioShop) gel electrophoresis at $200 \mathrm{~V}$ for 1 hour in $1 \mathrm{x}$ Tris-acetate-EDTA buffer and made visible by ethidium bromide staining and UV transillumination according to Sambrook et al., 1989.

\section{4- Sequencing of $16 \mathrm{~S}$ rRNA. \\ 4-1 Purification of the PCR}

Products were done according to manufacture instruction of QIAquick gel extraction kit (Qiagen).

\subsection{Sequencing reaction :}

A purified PCR product was sequenced in the forward and reverse directions on an Applied Biosystems 3130 automated DNA Sequencer (ABI, 3130, USA). Using a ready reaction Bigdye Terminator V3.1 cycle sequencing kit. (PerkinElmer/Applied Biosystems, Foster City, CA). A BLAST® analysis (Basic Local Alignment Search Tool) (Altschul et al., 1990) was initially performed to establish sequence identity to GenBank accessions. The sequence reaction was done according to the instruction of the manufacture as follows in table (2).

\subsection{Phylogenetic analysis:}

A comparative analysis of sequences was performed using the CLUSTAL W multiple sequence alignment program, version 1.83 of MegAlign module of Lasergene DNAStar software. Pairwise, designed by
Thompson et al., (1994), and phylogenetic analyses were done using maximum likelihood, neighbor joining and maximum parsimony in MEGA6 (Tamura et al., 2013).

Table (1): Preparation of master mix using Big dye Terminator V3.1 cycle sequencing kit.

\begin{tabular}{|l|l|}
\hline Reagent & Amount \\
\hline Big dye terminator v.3.1 & $2 \mu \mathrm{l}$ \\
\hline Primer & $1 \mu \mathrm{l}$ \\
\hline Template according to quality of & From 1 to $10 \mu \mathrm{l}$ \\
\hline Deionized water or PCR grade & Complete till to total \\
Water & volume become 20 $\mu 1$ \\
\hline Total volume & $20 \mu \mathrm{l}$ (Mix well, spin \\
& briefly) \\
\hline
\end{tabular}

\section{5- Antimicrobial sensitivity test}

Bacterial inoculums were prepared by overnight broth culture of the isolated bacteria according to Collee et al., (2007). Antibiotic susceptibility testing was carried out by disc diffusion method based on The Clinical and Laboratory Standards Institute (CLSI) guidelines using Muller-Hinton (MH) agar with and without sheep blood. Sensitivity pattern of the isolates were determined against thirteen selected antibiotic discs (sulfamethoxazoletrimethoprim (1.25-23.75 $\mu \mathrm{g})$, chloramphenicol $(30 \mu \mathrm{g})$, tetracycline $(30 \mu \mathrm{g}), \quad$ nitrofurantoin $\quad(300 \mu \mathrm{g})$, erythromycin $(15 \mu \mathrm{g})$, penicillin $\mathrm{G}(10 \mu \mathrm{g})$, nalidixic acid $(30 \mu \mathrm{g})$, clindamycin $(2 \mu \mathrm{g})$, kanamycin $(30 \mu \mathrm{g})$, cefotaxime $(30 \mu \mathrm{g})$, vancomycin $(30 \mu \mathrm{g})$, amoxicillin $(25 \mu \mathrm{g})$, cefazolin $(30 \mu \mathrm{g})$ (Oxiod). The dimeter of the inhibition zones was measured 
according to CLSI guidelines (CLSI

Catalogue, 2017)

\section{6- Ethics Statement}

All animals were handled according to the regulations of the Animal Ethics Committee at the Faculty of Veterinary Medicine, South Valley University, Qena, Egypt, with good animal practice following the guidelines of Research Code of Ethics (RCOE-SVU) at the South Valley University.

\section{RESULTS}

The complication associated with LSD infection were Pneumonia, edema in the brisket, Purulent osselets, nodules on eye lid, nostril, nose, fore head, purulent osselets, rhinitis , udder nodules and fistula sit-fast nodules, ulcer in leg, corneal opacity and endopthalmitis as showing in table (3), Fig (1a,b,c,d and 2e and f).

Table (3) Showing the recorded common microbiological, surgical complications and its isolated in bovine.

\begin{tabular}{|c|c|c|}
\hline $\begin{array}{l}\text { Cases } \\
\text { No. }\end{array}$ & $\begin{array}{l}\text { Surgical } \\
\text { complication }\end{array}$ & M.OS isolated \\
\hline \multirow[t]{2}{*}{ L S D } & Pneumonia, & Serratia \\
\hline & $\begin{array}{l}\text { Edema in the } \\
\text { brisket, Purulent } \\
\text { osselets, }\end{array}$ & odorifera \\
\hline \multirow[t]{2}{*}{ L S D } & Nodules on eye & Bacillus \\
\hline & $\begin{array}{l}\text { lid \&nostril and } \\
\text { Purulent osselets }\end{array}$ & licheniformis \\
\hline L S D & 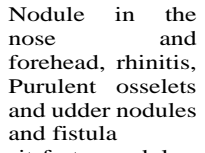 & $\begin{array}{l}\text { Enterococcus } \\
\text { faecium }\end{array}$ \\
\hline L S D & $\begin{array}{l}\text { sit-fast nodules, } \\
\text { ulcer in leg and } \\
\text { corneal opacity }\end{array}$ & $\begin{array}{l}\text { Paenibacillus } \\
\text { apiaries }\end{array}$ \\
\hline L S D & $\begin{array}{l}\text { Nodule in the } \\
\text { nose, forehead, } \\
\text { rhinitis and } \\
\text { endophthalmitis }\end{array}$ & $\begin{array}{l}\text { Microbacterium } \\
\text { hominis }\end{array}$ \\
\hline FMD & $\begin{array}{l}\text { Vesicular lesions, } \\
\text { coronary band } \\
\text { ulcer }\end{array}$ & $\begin{array}{l}\text { Bacillus } \\
\text { licheniformis }\end{array}$ \\
\hline & $\begin{array}{l}\text { Vesicular lesions } \\
\text { on the gum, }\end{array}$ & $\begin{array}{l}\text { Pseudomonas } \\
\text { mosselii }\end{array}$ \\
\hline FMD & $\begin{array}{l}\text { tongue } \\
\text { And coronary } \\
\text { band affection }\end{array}$ & \\
\hline FMD & $\begin{array}{l}\text { Swelling of } \\
\text { tongue, coronary } \\
\text { band affection } \\
\text { and vesicle on the } \\
\text { teat and abortion }\end{array}$ & Bacillus cereus \\
\hline FMD & $\begin{array}{l}\text { Vesicular lesions, } \\
\text { swelling r of } \\
\text { tongue coronary } \\
\text { band ulcer and } \\
\text { blister of the } \\
\text { udder }\end{array}$ & $\begin{array}{l}\text { Bacillus } \\
\text { licheniformis }\end{array}$ \\
\hline )- FMD & $\begin{array}{l}\text { Swelling of the } \\
\text { gum and mastitis } \\
\text { and claw over } \\
\text { lapping }\end{array}$ & $\begin{array}{l}\text { Trueperella } \\
\text { pyogens }\end{array}$ \\
\hline
\end{tabular}
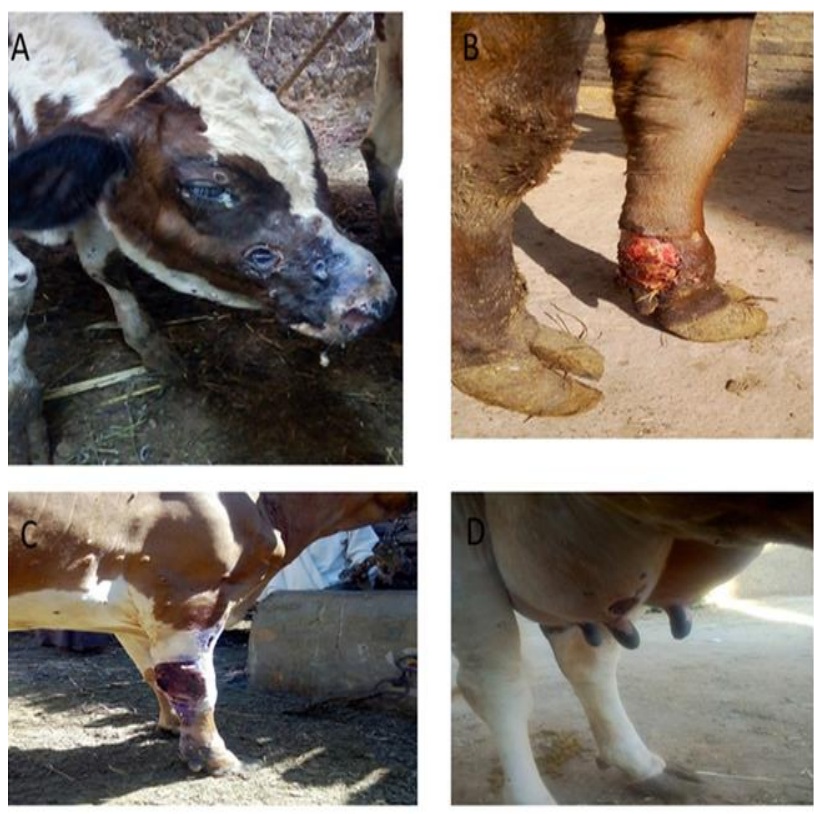

Figure (1): A: Sit fast nodules all over teat of 3 years old age cow as a complication of L.S.D B: Purulent osselets of 1 year old age bull as a complication of LSD C: Blister of fore limb of 3 year old age cow as a complication of LSD D: Udder nodules as a complication of LSD of 3 years old cow. 
Table (4) Showing the results of isolation of micro-organism and results of 16rRNA sequencing.

The most common complication associated with FMD were coronary band ulcer, vesicular lesions on the gum, tongue and Swelling of tongue and vesicle on the teat and abortion, blister of the udder and mastitis and claw over lapping as showing in (table 3 ) Fig (2g,h and $3 \mathrm{i}, \mathrm{k}$ and $\mathrm{l}$ ).

The results of conventional isolation and 16srRNA sequencing showing that the most than three antibiotics of different family of antibiotics table (5) and Fig (5).

\section{DISCUSSION}

The clinical picture of LSD in affected cattle is characterized by skin nodules. The nodules involve the skin and the mucosa of the respiratory tract, eyes, and genital tract. The nodules are characterized by their raised round shape,

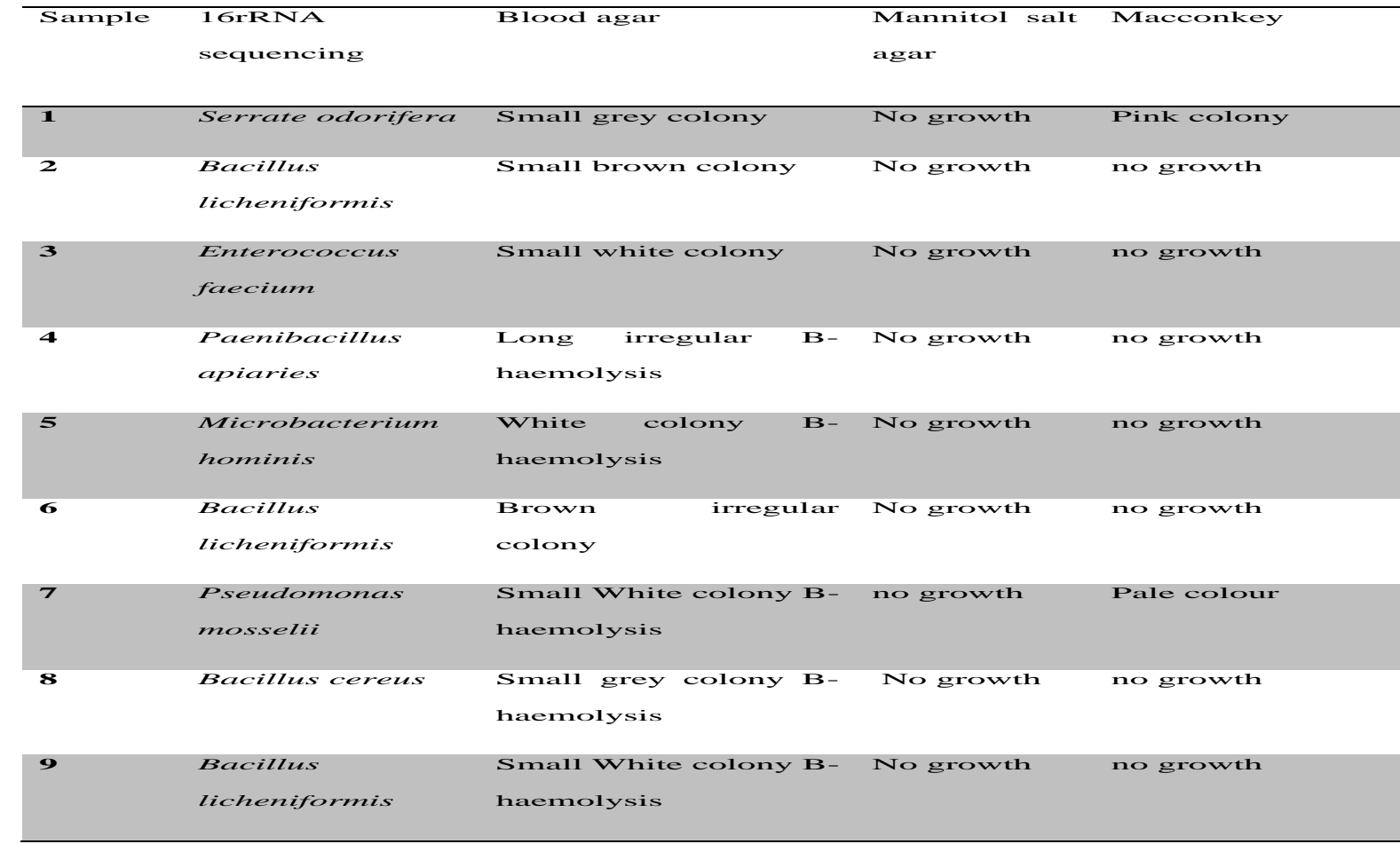

bacterial isolate were isolated from FMD and LSD were Bacillus licheniformis, Enterococcus faecium, Paenibacillus apiaries, Microbacterium hominis, Pseudomonas mosselii, Bacillus cereus and Trueperella pyogens table (4), Fig (4), Fig (1S) and Fig (2S). phylogenetic tree was carried by using neighbor joining to compare our isolates with other bacterial isolates in gene bank as showing in Fig (1S). The antibiotic sensitivity tests result for bacterial isolates showing the all bacterial isolates were resistant to more and pain. Nodules can also develop on the muzzle, buccal mucous membranes, nasal cavity, udder, and teats. Edema develops on the legs and brisket, and enlargement of regional lymph nodes. Suppuration, sloughing, and necrosis are most common complications of the secondary infection of LSD (Ahmed and Dessouki 2013).

Foot-and-mouth disease (FMD) is a devastating and debilitating viral disease of the cloven-hoofed animals and considered a threat to the animal industry globally. (Xu et al., 2013). The FMD is characterized by 
high rise of temperature, appearance of vesicles (blisters) on the mouth, muzzle, tongue, snout, nose, teats, inter digital space of feet and other hairless parts of skin (Teifke et al., 2012) which results into offfeeding and lameness. Therefore, direct economic losses due to FMD are attributed to losses in the meat and milk production (Ferrari et al., 2013).

In this study Serratia odorifera was isolated from male bull that was suffering organism had a characteristic strong potatolike odor when grew on 5\% sheep blood agar (Stock et al., 2002). The normal reservoir of $S$. odorifera is unidentified. Most strains have been isolated from cultivated mushrooms and from clinical specimens (bile, blood, pus and most commonly, sputum) of $S$. odorifra causing an invasive human infection Chmel. $\mathrm{H}$, (1988).

In this study $S$. odorifra are resistant

Table (5) Showing the results of sensitivity test of ten cases isolated

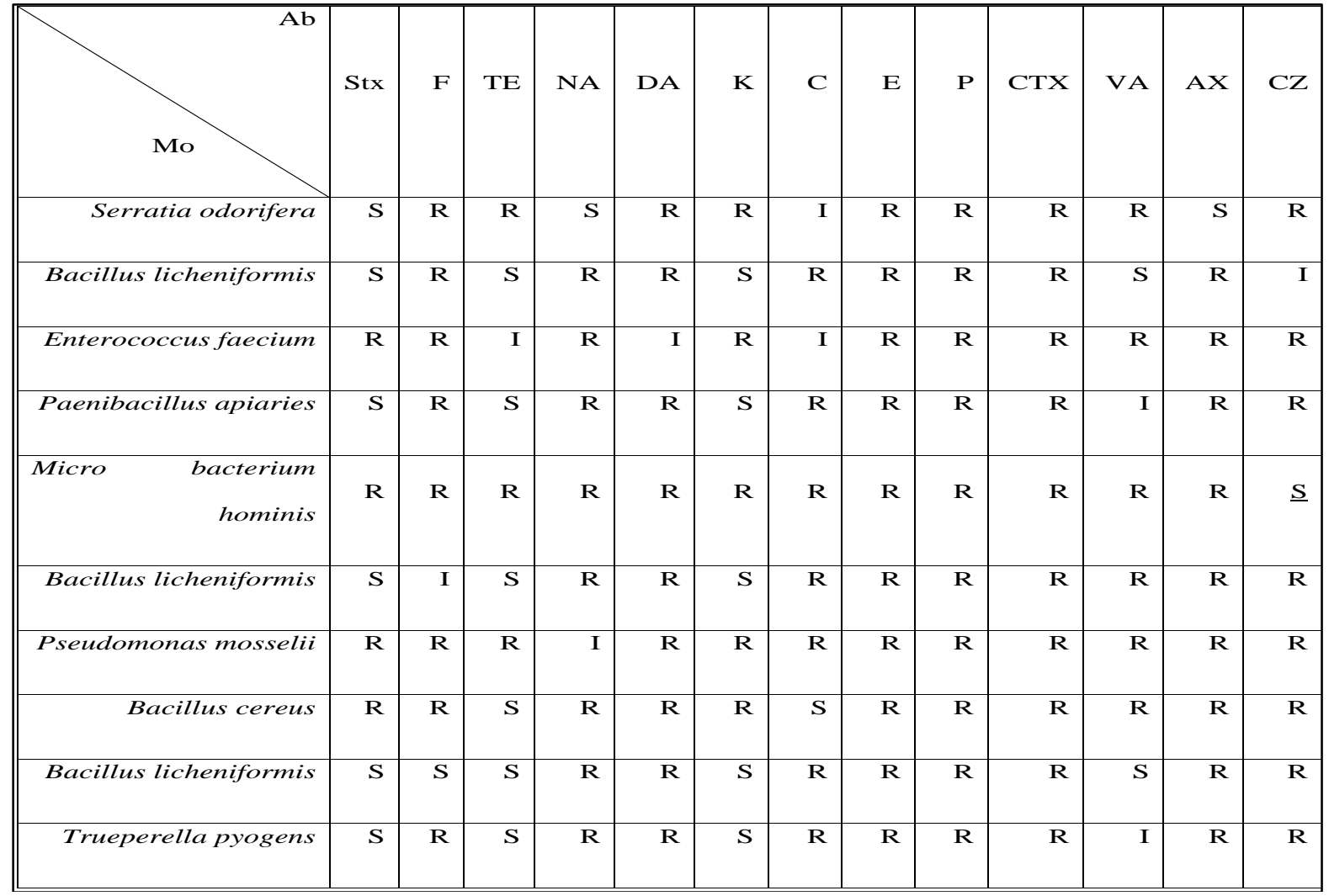

$\mathrm{Ab}=$ antibiotic disc, $\mathrm{M} . \mathrm{o}=$ Microorganism, Stx $=$ Sulfamethoxazole-trimethoprim

$\mathrm{F}=$ Nitrofurantoin, $\mathrm{TE}=$ Tetracycline, $\mathrm{NA}=$ Nalidixic acid, $\mathrm{DA}=$ Clindamycin, $\mathrm{K}=$ Kanamycin, $\mathrm{C}=$ Chlolmphenicol, E=Erythromycin, $\mathrm{P}=$ Penicillin, $\mathrm{CTX}=$ Cefotaxime, $\mathrm{VA}=$ Vancomycin, $\mathrm{AX}=\mathrm{Amoxicillin}$ and $\mathrm{CZ}=$ Cefazolin.

from LSD, animal was suffering from pneumonia, coughing, nasal discharge and nodules in mouth and eyes. Serratia odorifera species are rod-shaped Gramnegative bacteria, non-spore-forming bacilli that have peritrichous flagella. The to tetracycline, kanamycin, penicillin, cefotaxime and cefazolin and are sensitive to sulfamethoxazole-trimethoprim, nalidixic acid and amoxicillin. This agrees with Stock et al., (2003) who reported that $S$. odorifera isolates are naturally resistant 
to tetracyclines and chloramphenicol and are generally susceptible to sulfamethoxazole-trimethoprim, aminoglycosides, ticarcillin, piperacillin, cefotaxime, ceftriaxone, ceftazidime, cefepime, carbapenems, monobactams, and the quinolones .

In this study Bacillus Licheniformis was isolated from three cases (one case suffered from LSD and two cases suffered from FMD). The first case was a cow with LSD, which caused multiple nodules on udder and nose and purulent osselets. The second case was a male bull with FMD causing vesicle on the gum and tongue.

The third case was a cow affected with FMD and the clinical signs appeared as coronary band ulcer, swelling and blistering of the tongue. Bacillus Licheniformis is Gram-positive bacillus, spores of this bacterium redside in soil, bird feather especially chest, which make it desirable to be used for industrial purpose (Caldow et al., 1996). The presence of Bacillus Licheniformis as a complication of LSD and FMD may be attributed to the contamination of animal wounds with dust and soils.
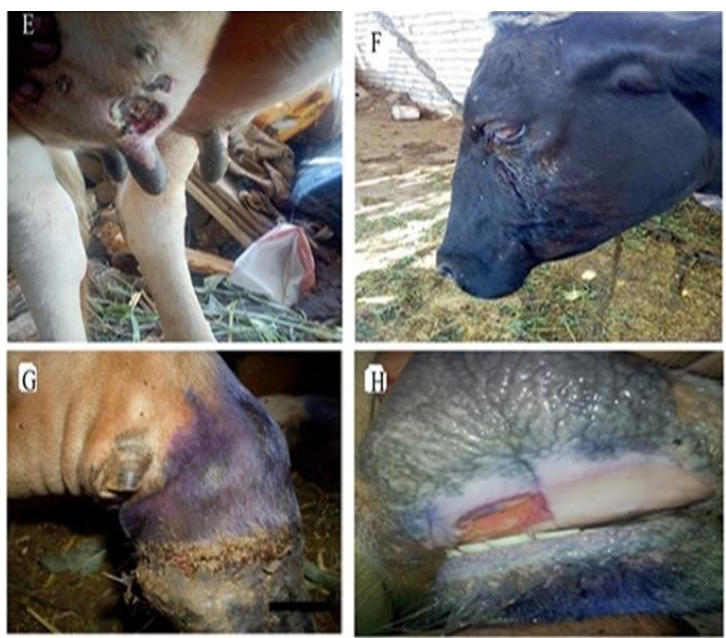

Figure (2): E: Udder fistula of 3years old cow as a complication of LSD F: Endophthalmitis of 4 years old cow as a complication of LSD;G: ruptured vesicle at coronary band of 1 years old bull as a complication of FMD; H: Vesicular stomatitis in the gum of 2years old age cow as a complication of FMD.

In this study Bacillus Licheniformis isolates were sensitive to sulfamethoxazoletrimethoprim and nalidixic acid and resistant to the other antibiotics. The clinical pictures and the isolated microorganisms were nearly similar to that mentioned by Bobkurov,1977 and frank,1981. The resistances of B. licheniformis to chloramphenicol and streptomycin were intrinsic (Ruegg 2010).

In this study E. faecium was isolated from a cow affected with LSD and was suffering from purulent osselets in the fore limb and udder fistula. Enterococcus faecium is one of the most important species of the genus Enterococci that includes 38 different species. It is a Gram-positive, facultative anaerobe that causes a variety of infections including, endocarditis, urinary tract infection, intra-abdominal infection and wound infection (Devriese et al., 2006; Murray et al., 2009 and Teixeira et al., 2011).
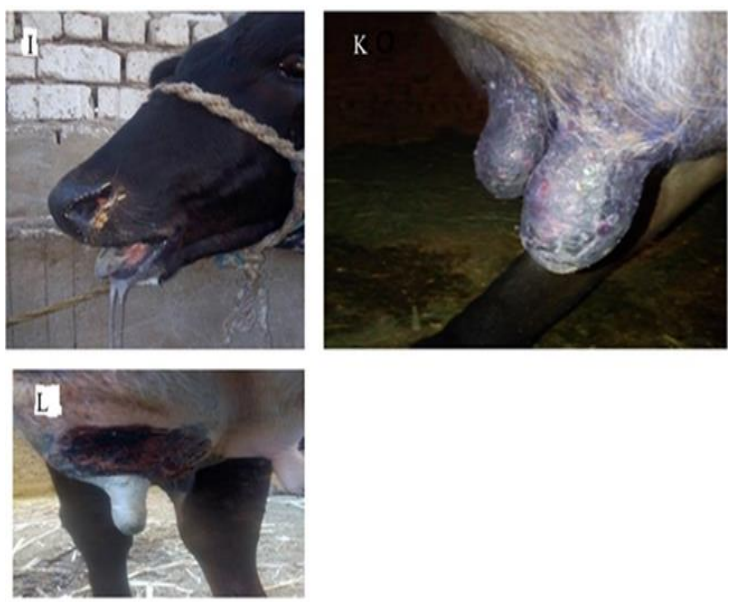

figure (3): I: Blisters in the mouth causing excess salivation of 2 years old age cow as a complication of FMD; K: Rupture of vesicle of teat of 4 years old age cow as a complication of FMD ; L: Blister of the udder of 3 years old cow as a complication of FMD. 
This is due to contamination of the wound as a secondary infection. Udder fistula was recorded in this study as a complication of LSD. The isolated bacteria were Enterococcus faecium the same result was reported by Abd-El- Hady (1993). In our study Enterococcus faecium was intermediately sensitive to tetracycline, clindamycin and chloramphenicol, but was resistant the other antibiotics. In our study the infection was coming from contamination of the wound or as a sequel of infection either by LSD or FMD.

In our study Paenibacillus apiaries was isolated from an animal with LSD and was contaminated wound and Sidfast nodules. Animal was located near a honeybee colony, so we suspect that Paenibacillus apiaries infection happened due to affection from insects (honeybee colony). Paenibacillus apiaries is a Grampositive bacillus, spore-forming bacterium that can invade honeybee larvae (Spence et al 2013). Paenibacillus apiaries isolate was sensitive to sulfamethoxazole-trimethoprim and kanamycin but resistant other antibiotics.

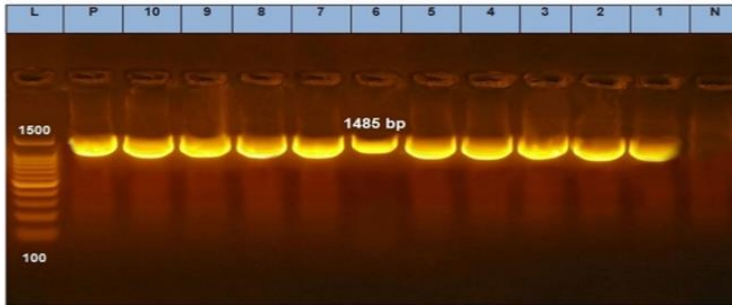

Figure (4): PCR results of 16rRNA among ten clinical isolates. Lane L: DNA ladder, Lane p: control positive, Lane N: control negative, lane 1-10 positive for $16 \mathrm{r}$ RNA gene.

Microbacterium hominis was isolated from the eyes of a cow affected with LSD. This is the first case reported in animals and caused endophthalmitis in the cow. Microbacterium hominis is a Grampositive, non-acid fast, non-capsule forming and non-spore-forming bacterium. It is isolated from lung aspiration and causes endophthalmitis in human (Funke et al 1995). The micro-organism was resistant to all antibiotics tested except cefazolin.

Pseudomnace mosselii was isolated from a cow affected with FMD. Clinincal symptoms included swelling of the tongue and gum and coronary band ulcer. The owner of this animal worked in a hospital; we suspect the infection to be of a nosocomial origin. Pseudomonas mosselii is a Gram-negative bacillus that is the third most common cause of nosocomial infection after Saphylococcus aureus and Escherichia coli (Abbasi et al.,2017). It affects mainly patients with cystic fibrosis, burns or immunodeficiency. The obtained data of antibiotic sensitivity of in our study showed Pseudomonas mosselii to be resistant to all antibiotics and this agree with (Khaledi and Meskini,2018).

Bacillus cereus was isolated from a cow affected with FMD. Clinically, it showed udder nodules and abortion. Bacillus cereus is a Gram-positive bacterium, motile, rod-shaped facultative anaerobic and $\beta$-hemolytic bacteria which affects both humans and animals Caldow et al., 1996 stated that the ability of bacillus species to infect the bovine placenta resulting in subsequent abortion, has been studied only for Bacillus cereus. The data of antibiotic sensitivity test of Bacillus cereues revealed sensitivity to tetracycline but was resistant to all antibiotics used in this study. 


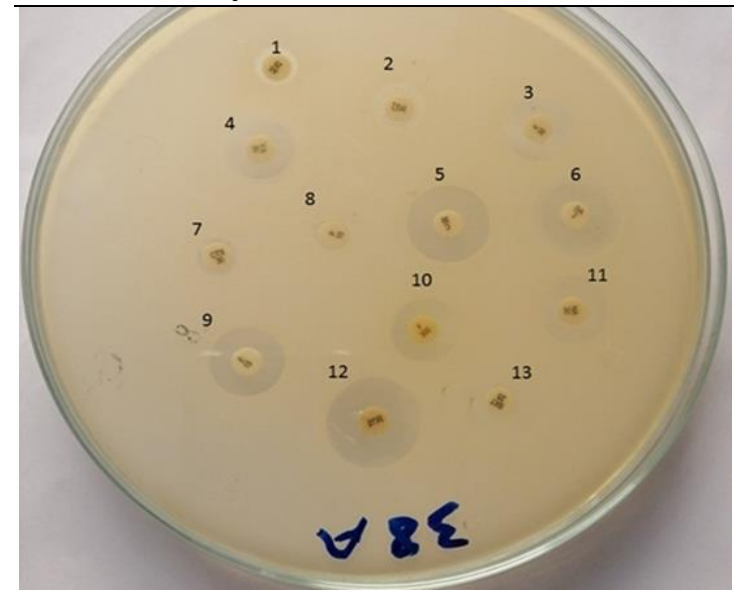

Fig (5): Sensitivity test using antibiotic disc.1(AX= Amoxicillin), 2 ( $\mathrm{CZ}=$ Cefazolin),3 ( $\mathrm{K}=$ Kanamycin), $4(\mathrm{VA}=$ Vancomycin $), 5(\mathrm{C}=$ Cholmphenicol $), 6$ (DA= Clinddamycin), 7 (CTX= Cefotaxime), $8(\mathrm{P}=$ Penicillin), $10 \quad(\mathrm{~F}=$ Nitrofurantoin $), 11 \quad$ (NA= Nalidixic acid ), 12 (TE=Tetracycline) and 13 (STX= Sulfamethoxazole-trimethoprim).

Trueperella pyogenes ( $T$. pyogenes) is a species of bacteria that are non-motile, facultative anaerobic and Gram-positive. over the last decades, $T$. pyogenes has been implicated as a cause of different clinical manifestations in domestic animals (Radostits et al 2007 and Greene et al 2012). Quinn et al (2011) stated that bovine intramammary infections caused by $T$. pyogenes are associated with the highest somatic cell count (SCC) in milk and significant losses in milk yield, as well as high percentages of nonfunctional quarters. T. pyogenes is the most important bacterial risk factor for clinical mastitis. $T$. pyogenes infections have been usually described to cause pyogenic infections in livestock (Radostits et al. 2007) causing bovine mastitis. In our study the Trueperella pyogenes was isolated from a cow affected with FMD which clinically appeared as swelling of the gum, tongue and mastitis and claw affection. The infection may be due to contamination of the udder or occurred as a secondary infection, this agrees with Quinn et al. (2011). Sogstad et al. (2005) Stated that claw overgrowth was highly recorded in dairy cows as a complication of FMD. T. pyogenes is a common pathogen that causes suppurative clinical manifestations among cattle and pigs, although it is specially reported as a causative agent of bovine mastitis (Ruegg, 2010). The micro-organism was sensitive to sulfamethoxazole-trimethoprim,

tetracycline and kanamycin but was resistant to other tested antibiotics. Diseases caused by $T$. pyogenes generate significant economic losses, mainly in cattle and swine breeding, causing a reduction of meat and milk yield. In addition. it decreases reproductive efficiency and sometimes it is necessary to cull diseased animals. The antimicrobial resistance in $T$. pyogenes is an emerging problem because of the common use of these drugs in agriculture (Feßler and Schwarz,2017).

In conclusion most bacterial isolates were isolated from LSD and FMD as complication were related to environment and human pathogens.

\section{ACKNOWLEDGMENTS}

Many thanks to Dr. Mahmoud Hamed Sabra, lecturer of Poultry and rabbit disease Faculty of Veterinary Medicine, South Valley University .for his help in analysis of sequencing data.

\section{CONFLICT OF INTEREST}

The authors declare that they do not have any conflict of interest.

\section{REFERENCES}

Abbasi, A., Maddah, S.M., Mahboubi, A., Khaledi, A., Vazini, H., Esmaeili, D., (2017): Investigate the inhibitory effects of Satureja khuzestanica essential oil against housekeeping fabD and exoA genes of Pseudomonas aeruginosa from hospital isolates using RT-PCR technique. Annals of Medical and 
Health Sciences Research 7, 246250 .

Abd El- Rahman A. O., Farag M. A., Samira El- Kilany, Eman, M.A, Manal Abo Yazed and Zeidan, S.(2006):Isolation and identification of FMDV during an outbreak of 2006 in Egypt. Kafr ELSheikh Vet. Med. J.: 4 (1). 451-464.

Abd-El- Hady,A.A. (1993): Studies on the prevalent udder and teat affections in dairy farms. M.V.Sc. Thesis, Faculty of Vet. Med., Cairo University.

Ahmed, A.M. and Dessouki, A.A. (2013) Abattoir-based survey and histopathological findings of lumpy skin dis-ease in cattle at Ismailia abattoir. Int. J. Biosci. Biochem. Bioinform., 3(4): 372375

Ahmed, H.A., Salem, S.A., Habashi, A.R., Arafa, A.A., Aggour, M.G., Salem, G.H., Gaber, A.S., Selem, O., Abdelkader, S.H., Knowles, N.J., Madi, M., ValdazoGonzalez, B., Wadsworth, J., Hutchings, G.H., Mioulet, V., Hammond, J.M. and King, D.P. (2012) Emergence of foot and-mouth disease virus SAT2 in Egypt during 2012. Transbound. Emerg. Dis., 59(6): 476-481.

Aidaros, H.A. (2002): Regional status and approaches to control and eradication of FMD in the Middle East and North Africa. Rev.sci.tech.Off.Int. Epiz., 21 (3): 451-458.

Altschul, S.F.; Gish, W.; Miller, W.; Myers, E.W. and Lipmanl, D.J. (1990):
Basic Local Alignment Search Tool. J. Mol. Biol. 215, 403-410.

Bauer K. (1997): Foot- and-mouth disease as zoonosis. Arch Viral Suppl.; 13:95-7.

Bebora, L. C. Odongo, M. O. Mbuthia P. G., Kagunya D. K., and Karaba W. W. (2007): Practical Bacteriology and Mycology Manual for Veterinary Students, University of Nairobi, College of Agriculture and Veterinary Services, Faculty of Veterinary Medicine, Department of Pathology, Microbiology and Parasitology.

Bobkurov, C. T. (1977): Suppurative and septic surgery 2nd Ed., Medetcina and physkoltora., Sofia.

Caldow GL, Buxton D, spence JA, Holisz J (1996): Diagnosis of bovine abortion in Scotland. Proc World Buiatrics Congr 19 (1): 203- 206.

Chmel H. (1988): Serratia odorifera biogroup 1 causing an invasive human infection. J Clin Microbio; 26:1244e5.

CLSI. (2017). Performance standards for antimicrobial susceptibility testing. 27th ed. CLSI supplement M100. Wayne, PA: Clinical and Laboratory Standards Institute. Performance standards for antimicrobial susceptibility testing. 27th ed. CLSI supplement M100. Wayne, PA: Clinical and Laboratory Standards Institute.

Collee JG, Miles RS, Watt B. Tests for identification of bac-teria. In: Collee JG, Duguid JP, Fraser AG, 
Marmion BP, Simmons. A, 2007):

Mackie and McCartney Practical Medical Microbiology. 14th ed, India: Churchill Livingstone, pp.131-149.

Daoud, A., Omar, A., El Bakry, M., Metwally, N., El Mekkawi, M. and El Kilany, S. (1988): Strains of footand-mouth Disease virus recovered from 1987 outbreak in Egypt. J. Egypt. Vet. Med. Ass., 48 (1): 6371.

Devriese L, Baele M, Butaye P (2006). The Genus Enterococcus. The Prokaryotes. New York: Springer, 163-174.

EL- kanawaty, Z. R. A (1989): some studies on lumpy skin disease. Thesis M. V. SC., Vet. Med., Zag. Univ., Benha

El- Nakashly, S.A., Abu Zeid, A.A., Samira El- Kilany and Abdel Aty, M.M. (1996): Isolation and identification of FMDV during an outbreak of 1993 in Egypt.7th Sci. Cong., 17-19 Nov. 1996, Fac. Et. Med., Assuit University, Egypt.

El-Mishad, A. (1991): Manual of practical microbiology, Modern Egyptian press,Cairo.

Fayed, A.A, (1988): Exotic Animal Diseases reported in Egypt. 2nd Sci., Cong., Egyptian society for cattle diseases, 5-7 Dec. 1993, Assiut, Egypt 249-256

Fayez Awadalla Salib and Ahmed Hassan, (2011): Osman Incidence of lumpy skin disease among Egyptian cattle in Giza Governorate, Egypt Department of Medicine and
Infectious Diseases, Faculty of

Veterinary Medicine, Cairo

University, Egypt. Veterinary World, 2011, Vol.4(4):162-167.

Ferrari G, Tasciotti L, Khan E and Kiani A (2013). Foot-and-mouth disease and its effect on milk yield: an economic analysis on livestock holders in Pakistan. Transbound. Emerg Dis. doi: 10.1111/tbed.12072.

Feßler, A.T.; Schwarz, S. (2017): Antimicrobial Resistance in Corynebacteriumspp., Arcanobacteriumspp., and Trueperella pyogenes. Microbiol. Spectr.,5(6). doi: 10.1128/microbiolspec.ARBA0021-2017. PMID: 29219109.

Forbes,B. A. Sahm, D. and Weissfield, A. S. Bailey and Scotts (2002): Diagnostic Microbiology, Mosby, St. Louis,Mo, USA, 11th edition,.34.

Frank,E.R.(1981): Veterinary surgery, 7th end., CBS publishers \& Distributors (India).

Fubini SL and Ducharme NG (2004). Farm animal surgery. 1st Edition, Saunders, 624.

Funke G, Falsen E, Barreau C. (1995): Primary identification of Microbacterium spp. encountered in clinical specimens as CDC coryneform group A-4 and A-5 bacteria. J Clin Microbiol; 33:18892.

Getty, R. (1975): Sisson and Grossman's anatomy of the Domestic Animals. 5th Ed. Philadelphia, Saunders. 
Ghoneim, N.H., Abdel- Karim, A.K.M., Laila El-Shehawy and AbdelMoein K. A. (2010): FMD in animals in Sharkia governorate, Egypt. Trans. \& Emerge. Dis. 57(1-2):19-21.

GOVS, (2009): Annual Report of infectious disease in Egypt. (Personal communication) General organization of veterinary Services.

Greene CE. (2012): Infectious diseases of the dog and cat. St. Louis: Elsevier; p. $484 \_485$.

Heidrich, H. J \& Renk, w (1967) : Diseases of the mammary glands of domestic animals .W . B. Saunders company, Philadelphia and London.

House, J. A. (1998): Foreign, Animal Diseases. "The Gray book", lumpy skin Disease. WWW. Vet. Uga .edu / VPP / gray - book / FAD / LSD.htm

Ismail, S. F. (1989): The clinical symptoms \& complications of lumpy skin disease. sci. cong., Fac. Vet. Med., Assiut Univ ., 379-384 .

Kandeil, A., El-Shesheny, R., Kayali, G., Moatasim, Y., Bagato, O Darwish, M., Gaffar, A., Younes, A., Farag, T., Kutkat, M.A. and Ali, M.A. (2013): Characterization of the recent outbreak of foot-and-mouth disease virus serotype SAT2 in Egypt. Arch. Virol., 158(3): 619627.

Kenawy, A. A. (1991): surgical Handling of lumpy skin disease in cows. Assiut Vet. Med. J., 26, (51), 235-240.
Khaledi, A., Meskini, M., (2018): A systematic review of the effect Satureja khuzestanica Jamzad and Zataria multiflora Boiss against Pseudomonas aeruginosa. Iranian Journal of Medical Sciences 21 (9), 201-2011.

Kossaibati, M. A. \& Esslemont, R. J. (1997): The cost of production diseases in dairy herds in England. Veterinary Journal, vol.154, pp 4151Journal of American Science, 2012; Incidence and Management of Bovine.

Knowles, N.; Wadsworth, J.; Reid, S.; Swabey, K.; Kholy, A.; AbdElrahman, A.; Soliman, H.; Ebert, K.; Ferris, N.; Hutchings, G.; Statham, R.; King, D. and Paton, D. (2007): Foot and Mouth Disease serotype A in Egypt. Emerging Infectious Disease 13(10): 15931596.

Lagacé, L.; Pitre, M.; Jacques, M. and Roy, D. (2004): Identification of the Bacterial Community of Maple Sap by Using Amplified Ribosomal DNA (rDNA) Restriction Analysis and rDNA Sequencing. applied and environmental microbiology, Apr. 2004, p. 2052-2060

Loth L, Osmani MG, Kalam MA, Chakraborty RK, Wadsworth J, Knowles NJ, Hammond JM and Benigno C (2011). Molecular characterization of foot and mouth disease virus; implications for disease control in Bangladesh. Transboundary and Emerging Diseases 58: 240-246. 
Moussa, A.A.M., Banoub, S.M., El-Said, T.E., Fahmy, F. and Bohm, H.O.

(1974a): Typing and subtyping of a strain of FMDV isolated from Sharquia. Province 1970. Presented to Arab Vet. Cong. Cairo 1970. J. Egypt. Vet. Med. Ass.34(3-4):413-419.

Murphy, Frederick A.; E. paul J. Gibbs; Marian C. Horzinek \& Michael J. studdert. (1999) Veterinary Virology. 3rd Edition, ch. 16 family poxviridae. Academic press London.

Murray P R, Rosenthal K S, Pfaller M A (2009): Enterococcus and other gram-positive cocci. Medical Microbiology (6th Ed), Philadelphia: Mosby Elsevier 243246

Quinn PJ, Markey BK, Leonard FC, Fitzpatrick ES, Fanning S, Hartigan PJ. (2011): Veterinary microbiology and microbial disease. UK: WileyBlackwell; p. 245_257

Quinn, P. J. Carter, M. E., Markey, B. and Carter G. R., (1994): Clinical veterinary microbiology, wolfe, London, (32).

Radostits OM, Gay CC, Hinchcliff KW, Constable PD. (2007): Veterinary medicine: a textbook of the diseases of cattle, horses, sheep, pigs, and goats. Philadelphia, PA: Saunders Elsevier; p. 722_724.

Ruegg PL. (2010): Mastitis in large animals. In: Kahn CM, editor.The Merck Veterinary Manual. Duluth, GA: Meck \& Co.,Inc; p. 1248_1257.
Salt JS. (1998): Persistent infections with foot-and-mouth disease virus. Top Trop Virol. 1:77-128

Sambrook, J.; Fritscgh, E.F.; and Mentiates (1989): Molecular coloning. A laboratory manual. Vol! Cold spring Harbor Laboratotry press, New York

Sears,P. M. Gonz'alez, R. N. Wilson, D. J. and Han, H. R. (1993): Procedures for Mastitis Diagnosis and Control," Veterinary Clinics of North America: Food Animal Practice, vol. 9, no. 3, pp. 445-468 (33).

Sogstad, A.M.; Fjeldaas, T. and Østeras, O.(2005): Lameness and claw lesions of the Norwegian red dairy cattle housed in free stalls in relation to environment, parity and stage of lactation. Acta Vet. Scand. 46, 20321.

Stock I, Burak S, Sherwood KJ, Gruger T, Wiedemann B. (2003): Natural antimicrobial susceptibilities of strains of 'unusual' Serratia species: S. ficarcia, S. fonticola, S. odorifera, S. plymuthica and S. rubidaea. J Antimicrobial Chemotherapy; 51:865e 85 .

Tamura, K., Stecher, G., Peterson, D., Filipski, A. and Kumar, S. (2013): MEGA6: molecular evolutionary genetics analysis version 6.0. Mol. Biol. Evol. 30, 2725-2729.

Teifke JP, Breithaupt A and Haas B (2012). Foot-and-mouth disease and its differential diagnoses. Tierarztl. Prax. Ausg. G Grosstiere Nutztiere. 40(4):225-37; 
Teixeira L M, Carvalho M G S, Shewmaker

P L, Facklam R R (2011): Manual of

Clinical Microbiology. Washington,

D C: ASM Press, 350-364

Thompson, J.D.; Higgins, D.G. and Gibson,

T.J. (1994): CLUSTAL W:

improving the sensitivity of progressive multiple sequence alignment through sequence weighting, position-specific gap penalties and weight matrix choice. Nucleic Acids Research, 22(22):4673-4680.

$\mathrm{Xu} \mathrm{L}$, Hurtle W, Rowland JM, Casteran KA, Bucko SM, Grau FR, ValdazoGonzalez B, Knowles NJ, King DP, Beckham TR and McIntosh MT (2013). Development of a universal RT-PCR for amplifying and sequencing the leader and capsid-coding region of foot-and-mouth disease virus. J. Virol. Meth. 189(1): 70-76. 